\title{
P92 - The prevalence of food sensitisation in children suffering from eczema
}

\author{
Agathi Karagiannidou ${ }^{1 *}$, Ioannis Xinias ${ }^{1}$, Sofia Botskariova', Nikolaos Karantaglis ${ }^{1}$, Olympia Ourailoglou' \\ Maria Fotoulaki ${ }^{2}$, Maria Emboriadou ${ }^{2}$, Aristidis Deligiannidis ${ }^{1}$, Antigoni Mavroudi $^{1}$
}

From 3rd Pediatric Allergy and Asthma Meeting (PAAM)

Athens, Greece. 17-19 October 2013

\section{Background}

Atopic dermatitis (eczema) is a highly pruritic chronic inflammatory skin disease. Food allergy has been strongly correlated with the development of persistence of atopic dermatitis.

\section{Aim of the study}

To investigate the association of food allergy in Greek children with atopic dermatitis.

\section{Patients and methods}

Eighty-eight (88) children with eczema (59 boys and 29 girls) aged between 12 months and 6 years were studied. All the children underwent allergological investigation with assignment of specific IgE antibodies (Elisa Method) to the following food allergens: $\alpha$ - lactalbumin, $\beta$-lactoglobulin, casein, milk proteins, egg white, egg yolk, beef, soy, wheat, and cod.

\section{Results}

Food sensitization occurred in 39 out of 88 children $(44,3 \%)$. The frequency distributions for elevated specific IgE antibodies to various food allergens in children with eczema are shown in the following Table (Table 1).

\section{Conclusions}

Food sensitization has a high prevalence of almost $44 \%$ among children with eczema.

Milk proteins are the most common food allergens implicated in children with eczema (27.25\%), followed by egg white (22.21\%), a-lactalbumin (21.2\%), egg yolk (12.11\%), $\beta$-lactalbumin (10.9\%) and wheat (8.7\%).

\begin{tabular}{|c|c|c|}
\hline Milk proteins & 27 & $25,00 \%$ \\
\hline Egg white & 22 & $21,00 \%$ \\
\hline a-lactabumin & 21 & $20,00 \%$ \\
\hline Egg yolk & 12 & $11,00 \%$ \\
\hline$\beta$-lactoglobulin & 10 & $9,00 \%$ \\
\hline Wheat & 8 & $7,00 \%$ \\
\hline Casein & 3 & $3,00 \%$ \\
\hline Soy & 3 & $3,00 \%$ \\
\hline Cod fish & 1 & $1,00 \%$ \\
\hline Beef & 0 & $0 \%$ \\
\hline Total & 39 & $100 \%$ \\
\hline
\end{tabular}

Beef, soy and cod fish are less common food allergens in children with eczema.

\section{Authors' details \\ $13^{\text {rd }}$ Pediatric Department, Aristotle University, Hippocration Hospital, Thessaloniki, Greece. ${ }^{2} 4^{\text {th }}$ Pediatric Department, Aristotle University, Papageorgiou Hospital, Thessaloniki, Greece.}

Published: 28 February 2014

doi:10.1186/2045-7022-4-S1-P147

Cite this article as: Karagiannidou et al:: P92 - The prevalence of food sensitisation in children suffering from eczema. Clinical and Translational Allergy 2014 4(Suppl 1):P147.

${ }_{1}^{1} 3^{\text {rd }}$ Pediatric Department, Aristotle University, Hippocration Hospital,

Thessaloniki, Greece

Full list of author information is available at the end of the article

(c) 2014 Karagiannidou et al; licensee BioMed Central Ltd. This is an Open Access article distributed under the terms of the Creative 